no positive sample has been traced in the walrus material examined up to date.

As was already predicted by Parnell ${ }^{5}$ in 1934 and by Leiper ${ }^{6}$ in 1938, trichinosis is to be considered as a major problem in the Arctic, and has a direct bearing on the health of the tribes inhabiting those regions as well as on that of explorers and sealers; the infection is moreover a danger by incapacitating the sledge dog, so indispensable to man in polar countries.

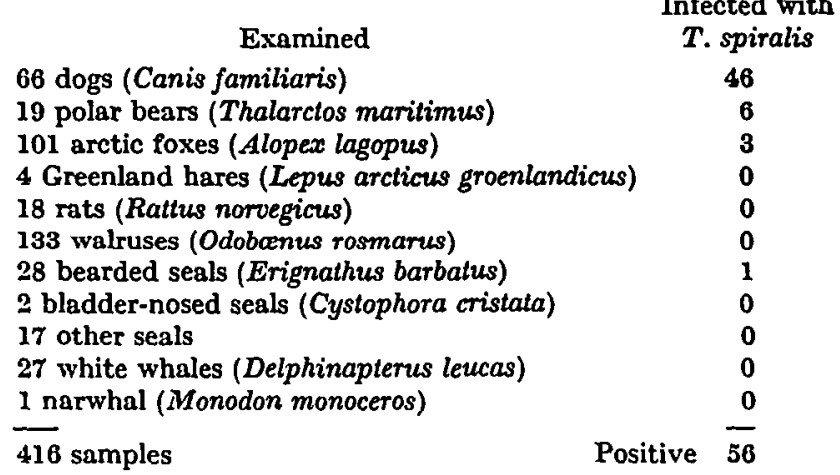

\title{
References
}

1 Thonzong, N. B., and others. Trikinose pan Gronland. Ugeskrift for Loger (Copenhagen), 110 Aarg., Nr. 21, 1948, p. 505-602.

2 Tromborg, N. B., and others. Trichinosis in Greenland. Acta pathologica et microbiologica Scandinavica (Copenhagen), Vol. 25, Fasc. 4, 1048, p. 778-94.

- Rotr, H. Serodiagnosis of trichinosis by microscopical testing with living Trichina larvx. Nature, Vol. 155, No. 3947, 1045, p. 758-59.

- Rory, H. Employment of serological and skin tests at outbreaks of trichinosis in the Alingsis and Borás districts (Sweden). Acta medica Scandinavica (Stockholm), Vol. 126, Fasc. 1, 1046, p. 17-33.

s Parnelr, J. W. Animal parasites of north-east Canada. Canadian Field Naturalist, Vol. 48, 1934, p. 111-15.

- Leiper, R. T. Trichinosis in arctic animals. Proceedings Zoological Sociely of London, Vol. 108 (Series C), No. 3, 1038, p. 13-14.

\section{RECENT SOVIET INTEREST IN BELLINGSHAUSEN'S ANTARCTIC VOYAGE OF 1819-21}

[Based on articles by B. G. Ostrovskiy in Izvestiya Vsesoyuznogo Geograficheskogo Obshchestva [Nezes of the All-Union Geographical Society] (Leningrad), Tom 81, No. 2, 1949, p. 239-49; L. S. Berg, ibid., p. 137-44; G. M. Tauber, ibid., Tom 81, No 4, 1949, p. 369-85; A. A. Grigoryev and D. M. Lebedev in Izvestiya Akademii Nauk SSSR. Seriya Geograficheskaya $i$ Geofizicheskaya [News of the Academy of Sciences of the U.S.S.R. Geographical and Geophysical Series] (Moscow), Tom 13, No. 3, 1949, p. 185-93; N. N. Zubov in Ogonek [The Flame] (Moscow), No. 12, March 1949, p. 21-23; S. V. Kalesnik in Priroda [Nature] (Leningrad), No. 8, 1949, p. 80-82; and on information from Soviet Monitor of 17 February 1949.]

In the U.S.S.R. there has recently been a revival of interest in Bellingshausen's voyage of 1819-21 to the Southern Ocean, in an effort to show that Bellingshausen discovered the antarctic mainland. This revival, which started in February 1949 and draws attention to Russia's first and only voyage of exploration in antarctic waters, apparently aims to foster public support for Soviet 
participation in any future international decision concerning territorial claims in the Antarctic. It is apparently forgotten that original discovery more than a hundred years ago, not followed up by official claims and recognition of these claims by other powers, is worth nothing in international law; but the subject is undoubtedly of historical interest.

It is not quite clear precisely which discovery of the expedition forms the basis for the Russian claim. On 28 January 1820 (16 January, old style), looking south from lat. $69^{\circ} 21^{\prime}$ S., long. $2^{\circ} 14^{\prime}$ W., Bellingshausen saw "an icefield strewn with hummocks". He was then very close to what is now called Kronprinsesse Märtha Land. On 17 February 1820 (5 February, old style), in the vicinity of lat. $69^{\circ} \mathrm{S}$., long. $16^{\circ} \mathrm{E}$., he saw something which was almost certainly land-now called Prinsesse Ragnhild Land-but which he assumed to be icebergs of very large dimensions. The following year, in January 1821, he discovered an island which he named Ostrov Petra I (now called Peter I Øy), and a stretch of coast which he called Bereg Aleksandra I (Alexander I coast, now called Alexander I Land, and recently found to be a large island lying close to the mainland). These incidents and discoveries-taken from Bellingshausen's own account of the voyage-are mentioned by the authors of recent Soviet articles on the Antarctic, and are jointly pul forward as proof of the fact that Bellingshausen discovered Antarctica.

With one exception, the Soviet accounts mention neither the voyage of Edward Bransfield, during which he sighted the north-western coast of Graham Land on 30 January 1820, nor that of Nathaniel B. Palmer, who sighted part of Graham Land on 17 November of the same year-events which render void the claim that discovery of land in January 1821 constitutes discovery of the antarctic mainland. The exception is the account by Grigor'yev and Lebedev. In it, Bransfield's discovery is denied because the authors have seen no evidence produced in support of it. Palmer's discovery is dismissed, after some argument, because "it is now known that the land [which Palmer saw] south of Deception Island is not the antarctic mainland but the mountainous island of North Graham Land" (also referred to as "Graham Island"); it is even implied that because Palmer was simply a sealer and had no pretensions as an explorer, his discoveries are not valid. None of these objections can be taken seriously. Bransfield's discovery is well supported by documentary evidence; ${ }^{1}$ and in Palmer's case the Soviet writers seem to have relied upon a map at least 12 years out of date. Sir Hubert Wilkins placed an island of "North Graham Land" on the map in 1928, but this island was proved to be part of the mainland largely by the British Graham Land Expedition of 1934-37.

The Soviet case for priority of discovery must therefore rest on the assertion that the hummocky ice seen on 28 January 1820 was, in fact, land. On 20 March 1948, a Soviet floating factory, the Slava, reached lat. $69^{\circ} 10^{\prime} \mathrm{S}$., long. $0^{\circ} 52^{\prime} \mathrm{W}$. - within about 40 miles of Bellingshausen's position on 28 January 1820, and E.N.E. of it. Those on board the Slava saw land very clearly

1 H[inks], A. R. On some misrepresentations of Antarctic history. Geographical Journal, Vol. 94, No. 4, 1939, p. 309-30. Gould, R. T. The charting of the South Shetlands, 1819-28. Mariner's Mirror, Vol. 27, No. 3, 1941, p. 206-42. 
-the weather was fine-and they state that in these waters the "coastal strip" does resemble hummocky ice. It is conceivable that what was seen in 1820 was ice-covered land, though it is more likely to have been shelf ice; Bellingshausen himself was far too careful and accurate to claim that he had seen land. In any case the evidence at present available in support of the Soviet contention is not strong enough to bear a claim of continental discovery. However, if there had been fine weather on this particular day, it is very likely that land would have been sighted, and the honour of discovering the antarctic continent might indeed have fallen to the Russians-by two days.

It is vexatious that arguments of this sort should revolve round Bellingshausen, for his voyage was a most remarkable one, and he certainly deserved to make more discoveries than he in fact made. Nevertheless, it seems important, in view of the political significance attached by the Russians to his explorations, that the sequence of events should be made clear.

From the historian's point of view, a satisfactory result of this revival of interest is the fact that several prime sources of information concerning Bellingshausen's voyage have been unearthed. Hitherto, there were only three available published accounts of the voyage by those taking part in it. These were Bellingshausen's own account, Dvukratnyye izyskaniya v Yuzhom Ledovitom okeane i plavaniye volkug sveta... [A two-fold expedition in the Southern Ocean and $a$ voyage round the world...] (St Petersburg, 1831), published in two volumes with an atlas; and two publications by I. M. Simonov, an astronomer and the only scientist of the expedition. Simonov's publications are called Slovo o uspekhakh plavaniya shlyupa "Vostolk" $i$ "Mirnyy" v Yuzhnoye Ledovitoye more... [On the successes of the voyage of the sloops "Vostok" and "Mirnyy" to the Southern Ocean...] (Kazan', 1822), which is the printed version of a lecture giving an outline of the expedition's activities, and Astronomicheskiye $i$ ficheskiye nablyudeniya professora Simonova, delannyye vo vremya puteshestviya yego okolo sveta na shlyupe Vostoke [Astronomical and physical observations by Professor Simonov, performed during his voyage round the world in the sloop "Vostok"] (St Petersburg, 1828).

The recent finds include one published work and three manuscripts. The published work is an anonymous book intitled Yuzhnyy polyus. Iz zapisok byvshego morskogo ofitsera [The South Pole. From the notes of a former naval officer] (St Petersburg, 1853). This is a description of the voyage, evidently written by an officer in the Mirnyy, and, since it frequently mentions four out of the sloop's five officers, there is little doubt that the author is the fifth, P. M. Novosil'skiy. The principal interest of this discovery is that no other account by anyone on the Mirnyy has previously been found. It is remarkable that this book apparently escaped the notice of earlier Russian enthusiasts for Bellingshausen, such as $\mathrm{Yu}$. M. Shokal'skiy and N. Vvedenskiy. The most important of the three manuscripts is I. M. Simonov's diary of the voyage. This diary, contained in twenty-five notebooks, was discovered in the archives of Kazan' University, where Simonov was first a professor and later rector. Another manuscript diary has also been brought to light-that of Yegor Kiselev, a seaman in the Vostok. The third manuscript is a copy of the 
instructions given by the President of the Academy of Fine Arts [Akademiya Khudozhestv] to the artist of the expedition, P. N. Mikhaylov. These instructions, which are detailed and show clearly what a great deal of hack-work was expected of the official artist before the days of photography, are largely reproduced in the paper by Ostrovskiy mentioned in the rubric.

- In view of the present political significance of everything concerned with Bellingshausen's voyage, there is every likelihood that all the recent discoveries will be published or re-published in the near future. It is to be hoped that the new documents will throw further light on the events of 28 January 1820.

TERENCE ARMSTRONG

\section{ARGENTINE AND CHILEAN DECREES RELATING TO THE ANTARCTIC, 1942-49}

[The texts of earlier decrees relating to Argentine and Chilean territorial claims in the Antarctic were reproduced in the Polar Record, No. 32, July 1946, p. 412-17, and No. 95/36, January-July 1948, p. 223-27. The texts of some further decrees, for which we are indebted to the Argentine and Chilean Embassies in London, are printed below.]

Translation:

\section{ARGENTINE DECREES}

\section{Argentine Decree of 12 February $1948^{1}$}

Ministry of Foreign Affairs and Worship-No. 3901 of 1948

"In view of Note No. 35/947 DRE of the Ministry of Foreign Affairs and "CONSIDERING:

"That it is convenient to initiate in Santiago de Chile the conversations agreed between the Republics of Argentina and Chile with regard to the rights which both countries exercise in the Antarctic Continent, the President of the Argentine nation decrees:

"Article 1.--His Excellency Ambassador Extraordinary and Plenipotentiary Dr Pascual La Rosa is appointed in the capacity of a Plenipotentiary Representative to initiate, on his way through Santiago de Chile to Bogotá, the conversations agreed with the Chilean Government.

"Article 2.-Technical advisers to the Envoys Extraordinary and Ministers Plenipotentiary will be: Doctor D. José Carlos Vitton and Doctor D. José Mara Cosentino.

"Article 3.-Assistant: Principal Assistant D. Lucio A. Fernández.

"Article 4.-The corresponding full powers will be issued through the Ministry of Foreign Affairs.

"Article 5.-The sum of $20,000 \mathrm{~m} / \mathrm{n}$ is assigned for expenditure in connexion with representation and subsistence, with instructions to submit accounts.

"Article 6.-Travelling expenses will be drawn in accordance with Decree No. 17,089 of 6 November 1946 and corresponding instructions.

"Article 7.-Passages and other expenditure necessitated by the present Decree will be covered under Annex 3, heading II, clause I, Item (a), Law 1, Part 22 of the budget for the year 1948.

1 Original text published in Bolétin Oficial (Buenos Aires), 23 February 1948. 